\title{
Enantioselective syntheses of carbocyclic nucleosides 5'-homocarbovir, epi-4'-homocarbovir, and their cyclopropylamine analogs using facially selective Pd-mediated allylations
}

\author{
Lawrence P. Tardibono, Jr. ${ }^{a}$, Marvin J. Miller ${ }^{\mathrm{a}, *}$, Jan Balzarini ${ }^{\mathrm{b}}$ \\ ${ }^{a}$ Department of Chemistry and Biochemistry, University of Notre Dame, Notre Dame, IN 46556, USA \\ ${ }^{\mathrm{b}}$ Rega Institute for Medical Research, Katholieke Universiteit Leuven, B-3000 Leuven, Belgium
}

\section{A R T I C L E I N F O}

\section{Article history:}

Received 6 September 2010

Received in revised form 24 November 2010

Accepted 29 November 2010

Available online 4 December 2010

\begin{abstract}
A B S T R A C T
Carbocyclic nucleosides (-)-5'-homocarbovir and (+)-epi-4'-homocarbovir were prepared from an acylnitroso-derived hetero Diels-Alder cycloadduct. A kinetic enzymatic resolution generated an enantiopure aminocyclopentenol and $\operatorname{Pd}(0)$-mediated decarboxylative allylations of allyl 2,2,2-trifluoroethyl malonates were used to install the $4^{\prime}$-hydroxyethyl groups. Late stage derivatization gave access to the cyclopropylamine analogs, (-)-5'-homoabacavir, and (+)-epi-4'-homoabacavir. All carbonucleoside target molecules were evaluated for antiviral activity.
\end{abstract}

(c) 2010 Elsevier Ltd. All rights reserved.

\section{Introduction}

Carbocyclic nucleosides have been extensively targeted due to their potent antiviral and anti-cancer activities. ${ }^{1}$ Naturally occurring deoxynucleotides are needed to synthesize viral DNA. Carbovir (-)-1 and related compounds are analogs of natural deoxynucleotides and compete for incorporation into the growing viral DNA chain. ${ }^{2}$ Incorporation of dideoxynucleosides such as carbovir results in chain termination and disruption of the viral replication process. ${ }^{3}$

In particular, carbovir (-)-1 has shown significant in vitro antiHIV activity through its triphosphate analog by inhibiting HIV-1 reverse transcriptase. ${ }^{2}$ Its congener, abacavir (-)-2, has a considerably improved toxicity profile and higher oral bioavailability. ${ }^{4}$ Abacavir is metabolized to the triphosphate of carbovir by a unique mechanism that circumvents formation of carbovir itself. ${ }^{5}$ Consequently, abacavir has in vitro activity and in vivo efficacy against HIV. It has been approved by the FDA for the treatment of HIV infection under the brand name Ziagen. ${ }^{6}$

Due to the important activity of carbocyclic nucleosides, there is continued interest in the syntheses of new analogs. One approach has been to extend the $4^{\prime}$-carbon side chain. ${ }^{7}$ Although the enantioselective syntheses of $5^{\prime}$-homocarbovir (-)-3a and $5^{\prime}$-homoabacavir (-)-3b have been reported $^{8}$ (Fig. 1 ), only $5^{\prime}$-homocarbovir $( \pm)-\mathbf{3} \mathbf{a}^{9}$ has been evaluated in antiviral assays and showed poor activity in limited testing. ${ }^{9 a}$ To further investigate the activity profiles of (-)-3a as well as the previously untested (-)-3b, we

\footnotetext{
* Corresponding author. Tel.: +1 574631 7571; fax: +1 574631 6652; e-mail address: mmiller1@nd.edu (M.J. Miller).
}

developed a new synthetic route from an acylnitroso-derived hetero Diels-Alder cycloadduct, which utilizes decarboxylative rearrangements of allyl 2,2,2-trifluroethylmalonates to install the $4^{\prime}$ hydroxyethyl side chain. The modification of a single step in the sequence allowed for access to the unprecedented epi-4' analogs $(+)-\mathbf{4 a}$ and $(+)-\mathbf{4 b}$.<smiles>Nc1nc2c(ncn2C2CC3(CO)CCC(C3)C2[In])c(=O)[nH]1</smiles><smiles></smiles><smiles>[X]c1nc(N)nc2c(C3C=CC(CCO)C3)ncn12</smiles>

$(-)-3 a \mathrm{X}=\mathrm{OH}, 5^{\prime}$-homocarbovir $(-)-3 \mathbf{b} \mathrm{X}=\mathrm{NHCH}\left(\mathrm{CH}_{2}\right)_{2}, 5^{\prime}$-homoabacavir $(+)-4 a \mathrm{X}=\mathrm{OH}$, epi-4'-homocarbovir
$(+)-4 \mathbf{b} \mathrm{X}=\mathrm{NHCH}\left(\mathrm{CH}_{2}\right)_{2}$, epi-4'-homoabacavir

\section{Results and discussion}

Our research group's continued interest in the syntheses of diverse carbocyclic nucleosides ${ }^{10,11}$ has led to the development of a reliable method for the synthesis of cyclopentenol $(-)-7 .{ }^{12}$ We recently reported the $\mathrm{Cp}_{2} \mathrm{TiCl}$-catalyzed reduction of Boc cycloadduct $( \pm)-\mathbf{6}^{13}$ 
The reaction was performed on large scale $(50 \mathrm{mmol})$ and an isolated yield of $79 \%$ was obtained after the resultant silylated alcohol was deprotected with a simple acidic work-up with $1 \mathrm{M} \mathrm{HCl}$ (Scheme 1). Kinetic enzymatic resolution of $( \pm)-7$ was achieved with commercially available immobilized Candida antarctica $B$ lipase to ultimately form the enantiopure alcohol (-)-7. ${ }^{12}$<smiles>CC(C)(C)OC(=O)NO</smiles>

5<smiles>CC(C)(C)NC1C=CC(O)C1</smiles>

$(-)-7$

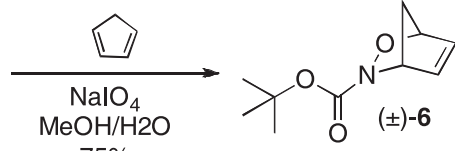

$75 \%$

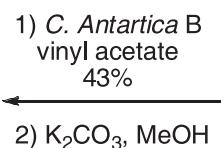

$99 \%$
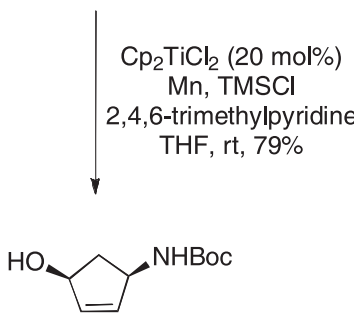

$( \pm)-7$
Scheme 1. Synthesis of aminocyclopentenol (-)-7.

Cyclopentenol (-)-7 was coupled with 3-oxo-3-(2,2,2-trifluoroethoxy)propanoic acid 8 to form allyl 2,2,2-trifluoroethyl malonate (-)-9 in high yield (Scheme 2). As previously reported, malonate (-)-9 underwent facile decarboxylative rearrangement in the presence of $\operatorname{Pd}(\mathrm{dba})_{2}$ and dppe to provide homoallylic ester (-)-10 with complete diastereo- and regio-control. ${ }^{14}$ Formation of the $\pi$-allyl palladium complex proceeded on the less hindered face and anti attack by the in situ generated nucleophilic alkoxy ethenolate species afforded the product with retention of configuration. Reduction of (-)-10 with 2 equiv of diisobutylaluminum hydride (DIBAL-H) yielded the desired alcohol $(-)-\mathbf{1 1} .{ }^{14}$ We then turned our attention to construction of the chloroguanine base.,15

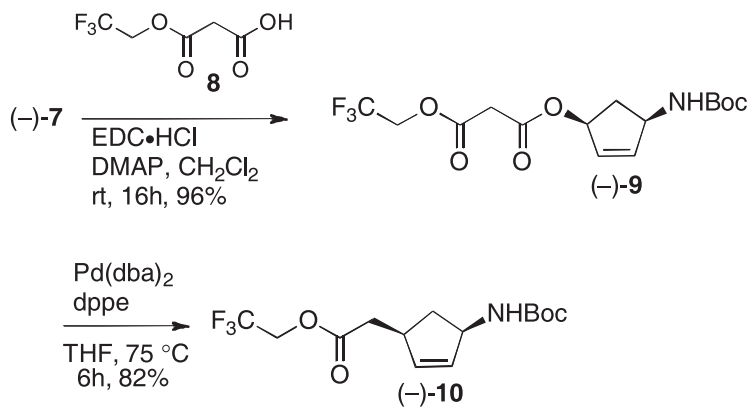

Scheme 2. Synthesis of homoallylic ester (-)-10.

Upon deprotection of the Boc group with $12 \mathrm{M} \mathrm{HCl}$, aminoalcohol (-)-11 underwent nucleophilic aromatic substitution with 2-amino-4,6-dichloropyrimidine to afford alcohol (+)-12 in 50\% yield over two steps (Scheme 3). Azo coupling of (+)-12 with 4chlorobenzenediazonium chloride followed by reduction of the resulting aryl azo compound with $\mathrm{Zn}$ in acetic acid afforded triaminopyrimidine (-)-13. 2-Propanol was selected as the co-solvent over ethanol due to the formation of side products from reaction with ethanol. ${ }^{16}$ Cyclization of (-)-13 with triethyl orthoformate in the presence of catalytic acid provided chloroguanine (-)-14. Careful monitoring of the reaction time was necessary to prevent substitution of the $6-\mathrm{Cl}$ group with ethanol, which formed an inseparable byproduct. ${ }^{17}$ Chloroguanine (-)-14 was refluxed in $0.33 \mathrm{M} \mathrm{NaOH}$ for $2 \mathrm{~h}$ to produce $5^{\prime}$-homocarbovir (-)-3a in $60 \%$ yield (Scheme 4). Alternatively, (-)-14 was stirred in 2-propanol at $70{ }^{\circ} \mathrm{C}$ in the presence of excess cyclopropylamine to form $5^{\prime}-$ homoabacavir (-)-3b in $80 \%$ yield.

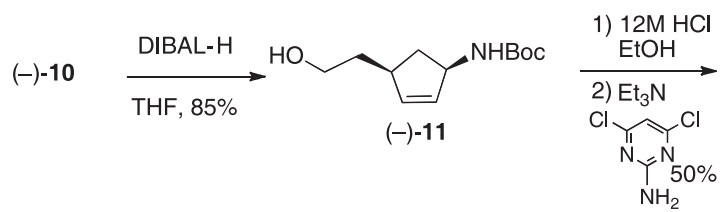

$(+)-12$<smiles>Nc1nc(Cl)cc(NC2C=CC(CCO)C2)n1</smiles>

$$
\begin{aligned}
& \text { 1) } 4-\mathrm{ClC}_{6} \mathrm{H}_{4} \mathrm{~N}_{2}{ }^{+} \mathrm{Cl}^{-} \\
& \mathrm{H}_{2} \mathrm{O} / \mathrm{AcOH} \\
& 80 \% \\
& \text { 2) } \mathrm{Zn} \\
& 75 \%
\end{aligned}
$$

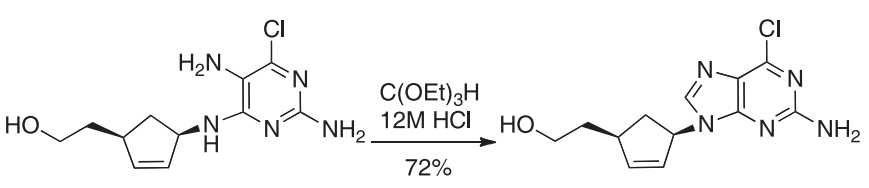

$(-)-13$

$(-)-14$

Scheme 3. Synthesis of intermediate (-)-14.<smiles>[X]c1nc(N)nc2c1ncn2[C@H]1C=C[C@H](CCO)C1</smiles>

(-)-3a: $\mathrm{X}=\mathrm{OH}, 5^{\prime}$-homocarbovir $(60 \%)$

(-)-3b: X=NHCH$\left(\mathrm{CH}_{2}\right)_{2}, 5^{\prime}$-homoabacavir (80\%)

Scheme 4. Synthesis of target carbonucleosides (-)-3b and (-)-3b.

trans-Carbocyclic nucleosides have been reported in the literature. $^{18}$ The synthetic routes towards these molecules were specifically designed around formation of the necessary anti-1,4aminocyclopentene. We envisioned a route that required minimal modification from our method to (-)-3a and (-)-3b. Cyclopentenol (-)-7 was treated with 3-oxo-3-(2,2,2-trifluoroethoxy)propanoic acid 8 under Mitsunobu conditions to form allyl 2,2,2-trifluoroethyl malonate (-)-15 in high yield with the expected inversion of configuration at $\mathrm{C}-4^{\prime}$ (Scheme 5$)$. $\mathrm{Pd}(0)$-mediated decarboxylative rearrangement of allyl 2,2,2-trifluoroethyl malonate (-)-15 proceeded with complete diastereo- and regio-control. The retention of configuration during this process is again noteworthy. Reduction of $(+)-\mathbf{1 6}$ with 2 equiv of diisobutylaluminum hydride (DIBAL-H) yielded the desired alcohol (+)-17. With the new C-4'
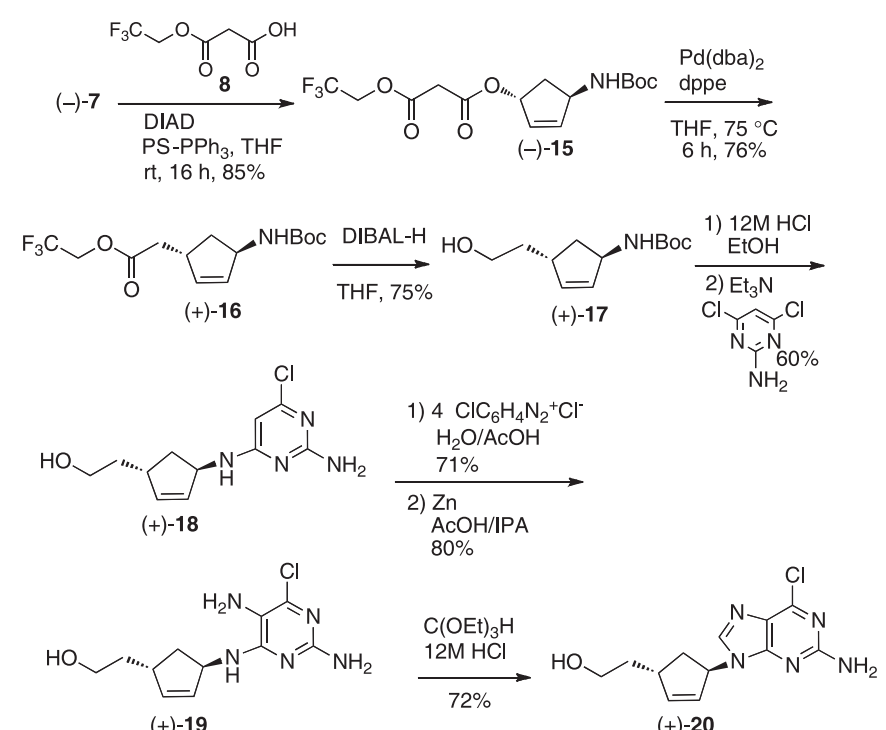

(+)-19

Scheme 5. Synthesis of intermediate (+)-20. 
stereochemistry established, construction of the chloroguanine base proceeded as described for the synthesis of the syn-1,4-disubstituted cyclopentene derivative. Chloroguanine $(+)-\mathbf{2 0}$ was synthesized in five steps from alcohol $(+)-\mathbf{1 7}$.

Chloroguanine $(+)-\mathbf{2 0}$ was refluxed in $0.33 \mathrm{M} \mathrm{NaOH}$ for $2 \mathrm{~h}$ to produce epi-4'-homocarbovir (+)-4a in $60 \%$ yield (Scheme 6). Alternatively, (+)-20 was stirred in 2-propanol at $70{ }^{\circ} \mathrm{C}$ in the presence of excess cyclopropylamine to form epi-4'-homoabacavir $(+)-\mathbf{4 b}$ in $90 \%$ yield. The epi-4' derivatives proved to be slightly more polar compounds than (-)-3a and (-)-3b but were amenable to purification by column chromatography.

$(+)-20$
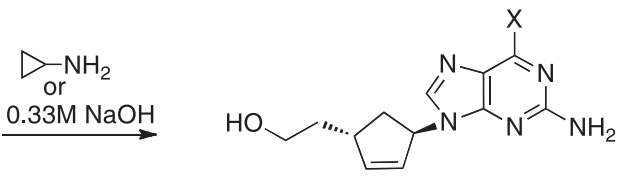

(+)-4a: $\mathrm{X}=\mathrm{OH}$, epi-4'-homocarbovir (60\%)

(+)-4b: $\mathrm{X}=\mathrm{NHCH}\left(\mathrm{CH}_{2}\right)_{2}$, epi-4'-homoabacavir (90\%)

Scheme 6. Synthesis of target carbonucleosides (+)-4a and (+)-4b.

Compounds (-)-3a, (-)-3b, (+)-4a, and (+)-4b were subjected to comprehensive screening for antiviral activity. They were tested for antiviral activity in human embryonic lung (HEL) [herpes simplex virus-1 (KOS), herpes simplex virus-2 (G), vaccinia virus, vesicular stomatitis virus, and herpes simplex virus-1 (TK-KOS ACVr), cytomegalovirus, varicella-zoster virus] cell cultures and CrandellRees feline kidney (CRFK) [anti-feline corona virus, anti-Feline herpes virus] cell cultures. The compounds were also evaluated for anti-HIV-1 and anti-HIV-2 activity in human T-lymphocyte (CEM) cells. None of the compounds exhibited significant antiviral activity or cytotoxicity. ${ }^{19}$

\section{Conclusion}

The decarboxylative allylations of allyl 2,2,2-trifluoroethyl malonates were the key steps en route to $5^{\prime}$-homo-carbocyclic nucleoside core structures. Inversion of the C $-4^{\prime}$ stereochemistry at the appropriate stage allowed for the synthesis of new epi-4'homo-carbocyclic nucleoside analogs without an increase in the number of synthetic transformations. Compounds (-)-3a, (-)-3b, $(+)-\mathbf{4 a}$, and $(+)-\mathbf{4 b}$ were evaluated for antiviral activity.

\section{Experimental section}

\subsection{General}

Commercially available reagents and anhydrous solvents were used without further purification unless otherwise specified. Tetrahydrofuran (THF) was distilled from sodium and benzophenone prior to use. Methylene chloride $\left(\mathrm{CH}_{2} \mathrm{Cl}_{2}\right)$ was distilled from calcium hydride prior to use. Glassware was oven dried for $16 \mathrm{~h}$ or flamedried under vacuum and purged with Ar prior to use. Reactions were monitored by thin-layer chromatography (TLC) on silica gel $60 \mathrm{~F}_{254}$ $(0.2 \mathrm{~mm})$ precoated aluminum foil and visualized with an ethanolic solution of $\mathrm{KMnO}_{4}$. Flash chromatography was performed with silica gel 60 (230-400 mesh). ${ }^{1} \mathrm{H}$ NMR and ${ }^{13} \mathrm{C}$ NMR spectra were recorded at ambient temperature on a Varian DirectDrive $600 \mathrm{MHz}$ instrument with the residual solvent peaks as internal standards. The line positions of multiplets are given in parts per million $(\delta)$ and the coupling constants $(J)$ are given as absolute values in hertz. Infrared spectra were recorded using an FT-IR spectrometer and are reported in $\mathrm{cm}^{-1}$. Melting points were obtained using a Thomas Hoover UniMelt capillary melting point apparatus and are uncorrected. Optical rotations were measured on a Rudolph Research Autopol III.
A Bruker MicrOTOF-II equipped with an electrospray ionization source was used for obtaining high resolution accurate mass measurements via flow-injection analyses.

Compound (-)-7 was obtained by dynamic enzymatic resolution as previously described. ${ }^{12}$ Compounds $( \pm)-\mathbf{7},(-)-\mathbf{9},(-)-\mathbf{1 0},(-)-\mathbf{1 1}$, $(-)-\mathbf{1 5}$, and $(+)-\mathbf{1 6}$ were obtained by methods previously described. ${ }^{14}$

4.1.1. (-)-2-Amino-9-((1R,4R)-4-(2-hydroxyethyl)cyclopent-2-enyl)$9 H$-purin-6-ol (3a). In a clean oven dried $15 \mathrm{~mL}$ sealed tube equipped with a Teflon screw cap, a solution of (-)-14 (18 mg, $0.064 \mathrm{mmol})$ in $0.33 \mathrm{M} \mathrm{NaOH}(1 \mathrm{~mL})$ was stirred at $100{ }^{\circ} \mathrm{C}$ for $2 \mathrm{~h}$. The reaction mixture was concentrated, adsorbed on silica gel, and purified by column chromatography (silica gel; eluted with $10-12 \% \mathrm{CH}_{3} \mathrm{OH}$ / $\mathrm{CH}_{2} \mathrm{Cl}_{2}$ ) to give $10 \mathrm{mg}$ of a (-)-3a as a pure white powder (60\%). Mp 216-217 ${ }^{\circ} \mathrm{C}, 220^{\circ} \mathrm{C} \mathrm{dec} ;[\alpha]_{\mathrm{D}}^{20}-14$ (c 0.1, DMSO); ${ }^{1} \mathrm{H}$ NMR $(600 \mathrm{MHz}$, DMSO- $\left.d_{6}\right) \delta 1.42-1.51(\mathrm{~m}, 2 \mathrm{H}), 1.64-1.71(\mathrm{~m}, 2 \mathrm{H}), 2.66$ (ddd, $J=8.4$, 8.4, 13.2 Hz, 1H), 2.77-2.84 (m, 1H), 3.41-3.51 (m, $1 \mathrm{H}), 4.45(\mathrm{t}, J=4.8$, $4.8 \mathrm{~Hz}, 1 \mathrm{H}), 5.27-5.33(\mathrm{~m}, 1 \mathrm{H}), 5.83$ (ddd, $J=1.8,1.8,6.0 \mathrm{~Hz}, 1 \mathrm{H}), 6.14$ (ddd, $J=1.8,1.8,6.0 \mathrm{~Hz}, 1 \mathrm{H}), 6.43$ (br s, 2H), 7.55 (s, 1H), 10.54 (br s, $1 \mathrm{H}$ ); ${ }^{13} \mathrm{C}$ NMR $\left(150 \mathrm{MHz}\right.$, DMSO- $\left.d_{6}\right) \delta 38.2,38.6,41.4,56.6,59.3,116.8$, 128.4, 134.8, 140.4, 150.8, 153.4, 156.8; IR (thin film) 1476, 1531, $1604,1683,2927,3108,3307 \mathrm{~cm}^{-1}$; HRMS (ESI) $m / z[\mathrm{M}+\mathrm{H}]^{+}$: calcd for $\mathrm{C}_{12} \mathrm{H}_{16} \mathrm{~N}_{5} \mathrm{O}_{2}^{+}, 262.1299$; found, 262.1285; HRMS (ESI) $m / z$ [M+Na] ${ }^{+}$: calcd for $\mathrm{C}_{12} \mathrm{H}_{15} \mathrm{~N}_{5} \mathrm{O}_{2} \mathrm{Na}^{+}$, 284.1118; found, 284.1107.

4.1.2. (-)-2-((1R,4R)-4-(2-Amino-6-(cyclopropylamino)-9H-purin9-yl)cyclopent-2-enyl)ethanol (3b). In a clean oven dried $15 \mathrm{~mL}$ sealed tube equipped with a Teflon screw cap, a solution of $(-)-14$ (20 $\mathrm{mg}, \quad 0.0715 \mathrm{mmol})$ and cyclopropylamine $(0.049 \mathrm{~mL}$, $0.715 \mathrm{mmol})$ in $i$-PrOH $(1 \mathrm{~mL})$ was stirred at $70^{\circ} \mathrm{C}$ for $4 \mathrm{~h}$. The reaction mixture was concentrated, adsorbed on silica gel, and purified by column chromatography (silica gel; eluted with $5-7 \%$ $\left.\mathrm{CH}_{3} \mathrm{OH} / \mathrm{CH}_{2} \mathrm{Cl}_{2}\right)$ to give $17 \mathrm{mg}$ of $(-)-3 \mathbf{b}$ as a clear oil $(80 \%) \cdot[\alpha]_{\mathrm{D}}^{20}$ $-27\left(c \mathrm{c}, 2, \mathrm{CH}_{3} \mathrm{OH}\right) ;{ }^{1} \mathrm{H}$ NMR (600 MHz, DMSO-d $\left.d_{6}\right) \delta 0.55-0.59(\mathrm{~m}$, $2 \mathrm{H}), 0.63-0.67(\mathrm{~m}, 2 \mathrm{H}), 1.43-1.52(\mathrm{~m}, 2 \mathrm{H}), 1.65-1.71(\mathrm{~m}, 1 \mathrm{H}), 2.67$ (ddd, $J=8.4,8.4,13.2 \mathrm{~Hz}, 1 \mathrm{H}), 2.77-2.85(\mathrm{~m}, 1 \mathrm{H}), 3.41-3.51(\mathrm{~m}, 2 \mathrm{H})$, 4.46 (t, $J=4.8,4.8 \mathrm{~Hz}, 1 \mathrm{H}$ ), 5.32-5.37 (m, 1H), 5.83 (br s, $2 \mathrm{H}$ ), 5.84 (ddd, $J=2.4,2.4,5.4 \mathrm{~Hz}, 1 \mathrm{H}$ ), 6.14 (ddd, $J=2.4,2.4,5.4 \mathrm{~Hz}, 1 \mathrm{H}$ ), 7.29 (br s, $1 \mathrm{H}), 7.56(\mathrm{~s}, 1 \mathrm{H}) ;{ }^{13} \mathrm{C}$ NMR (150 MHz, DMSO- $\left.d_{6}\right) \delta 6.4,23.8$, 38.2, 38.6, 41.3, 58.2, 59.3, 113.7, 128.7, 134.6, 140.1, 151.9, 155.9, 160.1; IR (thin film) 1488, 1590, 3203, $3322 \mathrm{~cm}^{-1}$; HRMS (ESI) $\mathrm{m} / \mathrm{z}$ $[\mathrm{M}+\mathrm{H}]^{+}$: calcd for $\mathrm{C}_{15} \mathrm{H}_{21} \mathrm{~N}_{6} \mathrm{O}^{+}, 301.1771$; found, 301.1761 .

4.1.3. (+)-2-Amino-9-((1R,4S)-4-(2-hydroxyethyl)cyclopent-2-enyl)9H-purin-6-ol (4a). In a clean oven dried $15 \mathrm{~mL}$ sealed tube equipped with a Teflon screw cap, a solution of $(+)-20(30 \mathrm{mg}, 0.107 \mathrm{mmol})$ in $0.33 \mathrm{M} \mathrm{NaOH}(1 \mathrm{~mL})$ was stirred at $100{ }^{\circ} \mathrm{C}$ for $2 \mathrm{~h}$. The reaction mixture was concentrated, adsorbed on silica gel and purified by column chromatography (silica gel; eluted with $15 \% \mathrm{CH}_{3} \mathrm{OH} / \mathrm{CH}_{2} \mathrm{Cl}_{2}$ ) to give $17 \mathrm{mg}$ of $(+)-\mathbf{4 a}$ as a white powder (60\%). Mp $169-170{ }^{\circ} \mathrm{C}$; $[\alpha]_{\mathrm{D}}^{20}+80\left(c \mathrm{0.05}\right.$, DMSO); ${ }^{1} \mathrm{H}$ NMR (600 MHz, DMSO-d $\left.d_{6}\right) \delta 1.42-1.49$ $(\mathrm{m}, 1 \mathrm{H}), 1.59-1.66(\mathrm{~m}, 1 \mathrm{H}), 1.97-2.08(\mathrm{~m}, 2 \mathrm{H}), 3.02-3.08(\mathrm{~m}, 1 \mathrm{H})$, $3.43-3.52(\mathrm{~m}, 2 \mathrm{H}), 4.64(\mathrm{t}, J=5.4,5.4 \mathrm{~Hz}, 1 \mathrm{H}), 5.32-5.37(\mathrm{~m}, 1 \mathrm{H}), 5.85$ (ddd, $J=2.4,2.4,5.4 \mathrm{~Hz}, 1 \mathrm{H}$ ), 6.19 (ddd, $J=1.8,1.8,6.0 \mathrm{~Hz}, 1 \mathrm{H}$ ), 6.42 (br s, $2 \mathrm{H}), 7.48$ (s, 1H), 10.53 (br s, $1 \mathrm{H}) ;{ }^{13} \mathrm{C}$ NMR (150 MHz, DMSO- $\left.d_{6}\right) \delta 38.4$, 38.5, 41.5, 58.9, 59.9, 117.3, 128.7, 135.3, 142.2, 151.1, 153.9, 157.3; IR (thin film) 1406, 1477, 1530, 1604, 1674, 2926, 3109, $3307 \mathrm{~cm}^{-1}$; HRMS (ESI) $m / z[\mathrm{M}+\mathrm{H}]^{+}$: calcd for $\mathrm{C}_{12} \mathrm{H}_{16} \mathrm{~N}_{5} \mathrm{O}_{2}^{+}, 262.1299$; found, 262.1307.

4.1.4. (+)-2-((1S,4R)-4-(2-Amino-6-(cyclopropylamino)-9H-purin9-yl)cyclopent-2-enyl)ethanol (4b). In a clean oven dried $15 \mathrm{~mL}$ sealed tube equipped with a Teflon screw cap, a solution of $(+)-\mathbf{2 0}$ (25 $\mathrm{mg}, 0.0893 \mathrm{mmol}$ ) and cyclopropylamine $(0.061 \mathrm{~mL}$, $0.893 \mathrm{mmol})$ in $i$-PrOH $(1.5 \mathrm{~mL})$ was stirred at $70{ }^{\circ} \mathrm{C}$ for $4 \mathrm{~h}$. The reaction mixture was concentrated, adsorbed on silica gel, and 
purified by column chromatography (silica gel; eluted with $6-8 \%$ $\mathrm{CH}_{3} \mathrm{OH} / \mathrm{CH}_{2} \mathrm{Cl}_{2}$ ) to give $21 \mathrm{mg}$ of $(+)-\mathbf{4 b}$ as a clear oil $(90 \%) \cdot[\alpha]_{\mathrm{D}}^{20}$ +33 (c $\left.0.1, \mathrm{CH}_{3} \mathrm{OH}\right) ;{ }^{1} \mathrm{H}$ NMR $\left(600 \mathrm{MHz}, \mathrm{CD}_{3} \mathrm{OD}\right) \delta 0.58-0.62(\mathrm{~m}$, $2 \mathrm{H}), 0.82-0.86(\mathrm{~m}, 2 \mathrm{H}), 1.57-1.64(\mathrm{~m}, 1 \mathrm{H}), 1.74-1.81(\mathrm{~m}, 1 \mathrm{H})$, 2.13-2.16 (m, 2H), 2.88-2.95 (m, 1H), 3.10-3.18 (m, 1H), 3.60-3.70 (m, 2H), 5.50-5.54 (m, 1H), 5.91 (ddd, $J=2.4,2.4,5.4 \mathrm{~Hz}, 1 \mathrm{H}), 6.28$ (ddd, $J=1.8,1.8,6.0 \mathrm{~Hz}, 1 \mathrm{H}), 7.59(\mathrm{~s}, 1 \mathrm{H}) ;{ }^{13} \mathrm{C} \mathrm{NMR}\left(150 \mathrm{MHz}, \mathrm{CD}_{3} \mathrm{OD}\right)$ $\delta$ 7.75, 24.5, 39.3, 39.7, 42.9, 60.6, 61.6, 115.1, 129.2, 137.1, 143.6, 151.7, 157.7, 162.1; IR (thin film) 1485, 1596, 3200, $3325 \mathrm{~cm}^{-1}$; HRMS (ESI) $m / z[\mathrm{M}+\mathrm{H}]^{+}$: calcd for $\mathrm{C}_{15} \mathrm{H}_{21} \mathrm{~N}_{6} \mathrm{O}^{+}, 301.1771$; found, 301.1788 .

4.1.5. (+)-2-((1R,4R)-4-(2-Amino-6-chloropyrimidin-4-ylamino)cyclopent-2-enyl)ethanol (12). To an EtOH (6.5 mL) solution of (-)-11 (720 mg, $3.17 \mathrm{mmol}$ ) was added $12 \mathrm{M} \mathrm{HCl}(0.33 \mathrm{~mL}, 3.80 \mathrm{mmol})$ and the reaction was stirred at $80{ }^{\circ} \mathrm{C}$ for $4 \mathrm{~h}$. The reaction mixture was concentrated to a light brown oil. To a solution of the oil and 2amino-4,6-dichloropyrimidine (574 $\mathrm{mg}, 3.33 \mathrm{mmol}$ ) in $n-\mathrm{BuOH}$ $(6.5 \mathrm{~mL})$ was added triethylamine $(1.10 \mathrm{~mL}, 7.92 \mathrm{mmol})$. The reaction was stirred in a sealed tube at $110{ }^{\circ} \mathrm{C}$ for 4 days. The reaction mixture was concentrated to a solid. The crude material was adsorbed on silica gel, and purified by column chromatography (silica gel; eluted with $1-2 \% \mathrm{CH}_{3} \mathrm{OH} / \mathrm{CH}_{2} \mathrm{Cl}_{2}$ to remove unreacted 2amino-4,6-dichloropyrimidine, then $5 \% \mathrm{CH}_{3} \mathrm{OH} / \mathrm{CH}_{2} \mathrm{Cl}_{2}$ to elute product) to afford $375 \mathrm{mg}$ of $(+)-\mathbf{1 2}$ as a $\tan$ solid (50\%). Mp $85-87{ }^{\circ} \mathrm{C} ;[\alpha]_{\mathrm{D}}^{20}+180\left(\right.$ c $\left.0.05, \mathrm{CH}_{3} \mathrm{OH}\right) ;{ }^{1} \mathrm{H}$ NMR $\left(600 \mathrm{MHz}, \mathrm{CDCl}_{3}\right)$ $\delta 1.27$ (ddd, $J=6.6,6.6,13.2 \mathrm{~Hz}, 1 \mathrm{H}), 1.39(\mathrm{br} \mathrm{s}, 1 \mathrm{H}), 1.57-1.64(\mathrm{~m}, 3 \mathrm{H})$, $1.75-1.81(\mathrm{~m}, 1 \mathrm{H}), 2.64(\mathrm{ddd}, J=7.8,7.8,13.2 \mathrm{~Hz}, 1 \mathrm{H}), 2.78-2.84(\mathrm{~m}$, $1 \mathrm{H}$ ), 3.68-3.78 (m, 2H), 4.82 (br s, $2 \mathrm{H}$ ), 5.73 (ddd, $J=1.8,1.8,5.4 \mathrm{~Hz}$, $1 \mathrm{H}), 5.8(\mathrm{~s}, 1 \mathrm{H}), 5.92-5.96(\mathrm{~m}, 1 \mathrm{H}) ;{ }^{13} \mathrm{C}$ NMR $\left(150 \mathrm{MHz}, \mathrm{CDCl}_{3}\right)$ $\delta 38.4,39.0,41.3,57.1,61.2,130.5,138.6,162.3,163.5$; IR (thin film) $1574,3317 \mathrm{~cm}^{-1}$; HRMS (ESI) $m / z[\mathrm{M}+\mathrm{H}]^{+}$: calcd for $\mathrm{C}_{11} \mathrm{H}_{16} \mathrm{ClN}_{4} \mathrm{O}^{+}$, 255.1013; found, 255.1013; HRMS (ESI) $\mathrm{m} / z$ [M+Na $]^{+}$: calcd for $\mathrm{C}_{11} \mathrm{H}_{15} \mathrm{ClN}_{4} \mathrm{ONa}^{+}$, 277.0832; found, 277.0827.

4.1.6. (-)-2-((1R,4R)-4-(2,5-Diamino-6-chloropyrimidin-4-ylamino) cyclopent-2-enyl)ethanol (13). A solution of $p$-chloroaniline $(125 \mathrm{mg}, 0.981 \mathrm{mmol})$ in $3 \mathrm{~N} \mathrm{HCl}(2 \mathrm{~mL})$ was stirred at $0{ }^{\circ} \mathrm{C}$. To this solution was added a solution of sodium nitrite $(68 \mathrm{mg}$, $0.981 \mathrm{mmol})$ in water $(0.8 \mathrm{~mL})$ and the mixture was allowed to stir at $0{ }^{\circ} \mathrm{C}$ for $10 \mathrm{~min}$. The resultant diazonium salt solution was added to a mixture of cyclopentene $(+)-\mathbf{1 2}(200 \mathrm{mg}, 0.785 \mathrm{mmol})$, acetic acid $(4 \mathrm{~mL})$, water $(4 \mathrm{~mL})$, and sodium acetate trihydrate $(1.6 \mathrm{~g})$. The reaction mixture was stirred overnight at $\mathrm{rt}$. The yellow precipitate was filtered and washed with cold water until the eluting filtrate was $\mathrm{pH}$ 7. The solids were dried under vacuum to yield $260 \mathrm{mg}$ of product (84\%). A portion (180 $\mathrm{mg}$ ) of the material was dissolved in water/i-PrOH ( $5 \mathrm{~mL} / 5 \mathrm{~mL})$ and $\mathrm{Zn}$ dust $(296 \mathrm{mg}, 4.53 \mathrm{mmol})$ was added. The mixture was stirred at $90{ }^{\circ} \mathrm{C}$ for $4 \mathrm{~h}$. The reaction mixture was concentrated to a solid. The crude material was adsorbed on silica gel and purified by column chromatography (silica gel; eluted with $2-5 \% \mathrm{CH}_{3} \mathrm{OH} / \mathrm{CH}_{2} \mathrm{Cl}_{2}$ to remove $p$-chloroaniline and other impurities, then $6-7 \% \mathrm{CH}_{3} \mathrm{OH} / \mathrm{CH}_{2} \mathrm{Cl}_{2}$ to elute product) to afford $93 \mathrm{mg}$ of (-)-13 as a pink oil (76\%). $[\alpha]_{\mathrm{D}}^{20}-36$ (c $0.05, \mathrm{CH}_{3} \mathrm{OH}$ ); ${ }^{1} \mathrm{H}$ NMR $\left(600 \mathrm{MHz}, \mathrm{CD}_{3} \mathrm{OD}\right.$ ) $\delta 1.28$ (ddd, $J=6.6,6.6$, $13.2 \mathrm{~Hz}, 1 \mathrm{H}), 1.54-1.61(\mathrm{~m}, 1 \mathrm{H}), 1.75-1.81(\mathrm{~m}, 1 \mathrm{H}), 2.66(\mathrm{ddd}, J=7.8$, 7.8, $13.2 \mathrm{~Hz}, 1 \mathrm{H}), 2.73-2.80(\mathrm{~m}, 1 \mathrm{H}), 3.60-3.68(\mathrm{~m}, 2 \mathrm{H}), 5.09-5.13$ ( $\mathrm{m}, 1 \mathrm{H}$ ), 5.77 (ddd, $J=1.8,1.8,5.4 \mathrm{~Hz}, 1 \mathrm{H}$ ), 5.91 (ddd, $J=1.8,1.8,5.4 \mathrm{~Hz}$, $1 \mathrm{H}) ;{ }^{13} \mathrm{C}$ NMR $\left(150 \mathrm{MHz}, \mathrm{CD}_{3} \mathrm{OD}\right) \delta 39.7,40.5,42.6,58.3,61.6,114.6$, 132.7, 138.6, 143.0, 157.3, 158.2; IR (thin film) 1440, 1502, 1571, 2925 , $3329 \mathrm{~cm}^{-1}$; HRMS (ESI) $\mathrm{m} / z[\mathrm{M}+\mathrm{H}]^{+}$: calcd for $\mathrm{C}_{11} \mathrm{H}_{17} \mathrm{ClN}_{5} \mathrm{O}^{+}$, 270.1132 ; found, 270.1122 .

4.1.7. (-)-2-((1R,4R)-4-(2-Amino-6-chloro-9H-purin-9-yl)cyclopent-2-enyl)ethanol (14). A mixture of (-)-13 (93 $\mathrm{mg}$, $0.345 \mathrm{mmol})$, triethyl orthoformate $(2 \mathrm{~mL})$, and $12 \mathrm{M} \mathrm{HCl}$ $(0.087 \mathrm{~mL})$ was stirred overnight at $\mathrm{rt}$. The suspension was concentrated under high vacuum. A dilute solution of hydrochloric acid $(0.5 \mathrm{M}, 4 \mathrm{~mL})$ was added and the mixture was stirred at $\mathrm{rt}$ for $1 \mathrm{~h}$. The mixture was neutralized to $\mathrm{pH} 8$ with $1 \mathrm{M}$ sodium hydroxide and concentrated to solids. The crude material was adsorbed on silica gel and purified by column chromatography (silica gel; eluted with $8 \% \mathrm{CH}_{3} \mathrm{OH} / \mathrm{CH}_{2} \mathrm{Cl}_{2}$ ) to afford $70 \mathrm{mg}$ of (-)-14 as white powder (72\%). Mp 70-71 ${ }^{\circ} \mathrm{C}$; $[\alpha]_{\mathrm{D}}^{20}-112$ (c 0.1, $\left.\mathrm{CH}_{3} \mathrm{OH}\right) ;{ }^{1} \mathrm{H}$ NMR $\left(600 \mathrm{MHz}, \mathrm{CD}_{3} \mathrm{OD}\right) \delta 1.59-1.66(\mathrm{~m}, 2 \mathrm{H})$ $1.81-1.87$ (m, 1H), 2.85 (ddd, $J=7.8,7.8,13.2 \mathrm{~Hz}, 1 \mathrm{H}), 2.92-2.99$ (m, $1 \mathrm{H}$ ), 3.60-3.69 (m, 2H), 5.55-5.60 (m, $1 \mathrm{H}), 5.90$ (ddd, $J=2.4,2.4$, $5.4 \mathrm{~Hz}, 1 \mathrm{H}), 6.24$ (ddd, $J=2.4,2.4,5.4 \mathrm{~Hz}, 1 \mathrm{H}), 8.03(\mathrm{~s}, 1 \mathrm{H}) ;{ }^{13} \mathrm{C} \mathrm{NMR}$ $\left(150 \mathrm{MHz}, \mathrm{CD}_{3} \mathrm{OD}\right) \delta 39.5,39.7,43.3,61.5,61.6,125.4,129.0,142.5$, 142.6, 151.6, 155.1, 161.7; IR (thin film) 1402, 1468, 1507, 1562, 1612, 2928, 3211, $3331 \mathrm{~cm}^{-1}$; HRMS (ESI) $\mathrm{m} / \mathrm{z}[\mathrm{M}+\mathrm{Na}]^{+}$: calcd for $\mathrm{C}_{12} \mathrm{H}_{14} \mathrm{ClN}_{5} \mathrm{ONa}^{+}$, 302.0772; found, 302.0785.

4.1.8. (+)-tert-Butyl (1R,4S)-4-(2-hydroxyethyl)cyclopent-2-enylcarbamate (17). A solution of (+)-16 (390 $\mathrm{mg}, 1.16 \mathrm{mmol})$ in anhydrous THF (3.5 mL) was cooled to $-78{ }^{\circ} \mathrm{C}$. The mixture was treated dropwise with DIBAL-H (1 M in THF)(3.5 mL, $3.5 \mathrm{mmol})$ and stirred for $3 \mathrm{~h}$ while warming to rt. To the mixture was added $50 \mathrm{~mL}$ of satd Rochelle salt solution and $20 \mathrm{~mL}$ of EtOAc and the mixture was stirred for $1 \mathrm{~h}$. The organic layer was separated and the aqueous phase was washed with EtOAc $(3 \times 20 \mathrm{~mL})$. The combined organics were then washed with satd $\mathrm{NaCl}$, dried over anhydrous sodium sulfate and concentrated to an oil. Purification by column chromatography (silica gel; eluted with $60 \%$ EtOAc/hexanes) provided $190 \mathrm{mg}$ of $(+)-17$ as a clear oil (75\%). $[\alpha]_{\mathrm{D}}^{20}+138\left(\mathrm{c} 0.05, \mathrm{CH}_{2} \mathrm{Cl}_{2}\right) ;{ }^{1} \mathrm{H}$ NMR $\left(600 \mathrm{MHz}, \mathrm{CDCl}_{3}\right) \delta 1.20-1.27(\mathrm{~m}, 1 \mathrm{H}), 1.44(\mathrm{~s}, 9 \mathrm{H}), 1.52-1.60$ $(\mathrm{m}, 1 \mathrm{H}), 1.66-1.72(\mathrm{~m}, 1 \mathrm{H}), 1.80-1.87(\mathrm{~m}, 1 \mathrm{H}), 1.88-1.94(\mathrm{~m}, 1 \mathrm{H})$, 2.89-2.96 (m, 1H), 3.64-3.75 (m, 2H), 4.44-4.51 (m, 1H), 4.69-4.77 (m, 1H), 5.70 (ddd, $J=2.4,2.4,5.4 \mathrm{~Hz}, 1 \mathrm{H}$ ), 5.89 (dddd, $J=1.8,1.8,1.8,5.4 \mathrm{~Hz}, 1 \mathrm{H}) ;{ }^{13} \mathrm{C}$ NMR $\left(150 \mathrm{MHz}, \mathrm{CDCl}_{3}\right) \delta 28.4,38.4$, 38.6, 40.7, 56.2, 61.5, 79.3, 131.1, 138.6, 155.3; IR (thin film) 1521, 1684, 2929, $3330 \mathrm{~cm}^{-1}$; HRMS (ESI) $\mathrm{m} / \mathrm{z}[\mathrm{M}+\mathrm{H}]^{+}$: calcd for $\mathrm{C}_{12} \mathrm{H}_{22} \mathrm{NO}_{3}^{+}, 228.1600$; found, 228.1597; HRMS (ESI) $\mathrm{m} / \mathrm{z}[\mathrm{M}+\mathrm{Na}]^{+}$: calcd for $\mathrm{C}_{12} \mathrm{H}_{21} \mathrm{NO}_{3} \mathrm{Na}^{+}$, 250.1419; found, 250.1414 .

4.1.9. (+)-2-((1S,4R)-4-(2-Amino-6-chloropyrimidin-4-ylamino $) c y-$ clopent-2-enyl)ethanol (18). To an EtOH $(1.6 \mathrm{~mL})$ solution of $(+)-\mathbf{1 7}$ (180 mg, $0.791 \mathrm{mmol})$ was added $12 \mathrm{M} \mathrm{HCl}(0.079 \mathrm{~mL}, 0.791 \mathrm{mmol})$ and the reaction was stirred at $80^{\circ} \mathrm{C}$ for $4 \mathrm{~h}$. The reaction mixture was concentrated to a light brown oil. To a solution of the oil and 2amino-4,6-dichloropyrimidine (143 $\mathrm{mg}, 0.831 \mathrm{mmol}$ ) in $n$-BuOH $(2 \mathrm{~mL})$ was added triethylamine $(0.275 \mathrm{~mL}, 1.98 \mathrm{mmol})$. The reaction was stirred in a sealed tube at $110^{\circ} \mathrm{C}$ for 4 days. The reaction mixture was concentrated to a solid. The crude material was adsorbed on silica gel and purified by column chromatography (silica gel; eluted with $1-3 \% \mathrm{CH}_{3} \mathrm{OH} / \mathrm{CH}_{2} \mathrm{Cl}_{2}$ to remove unreacted 2amino-4,6-dichloropyrimidine, then $3-4 \% \mathrm{CH}_{3} \mathrm{OH} / \mathrm{CH}_{2} \mathrm{Cl}_{2}$ to elute product) to afford $125 \mathrm{mg}$ of $(+)-\mathbf{1 8}$ as a tan oil $(60 \%) \cdot[\alpha]_{\mathrm{D}}^{20}+42(c$ $\left.0.1, \mathrm{CH}_{2} \mathrm{Cl}_{2}\right) ;{ }^{1} \mathrm{H}$ NMR $\left(600 \mathrm{MHz}, \mathrm{CDCl}_{3}\right) \delta 1.54-1.65(\mathrm{~m}, 3 \mathrm{H})$, $1.68-1.77(\mathrm{~m}, 1 \mathrm{H}), 1.87-1.99(\mathrm{~m}, 3 \mathrm{H}), 2.94-3.03(\mathrm{~m}, 1 \mathrm{H}), 3.67-3.77$ (m, 2H), 4.80 (br s, 2H), 5.76 (ddd, $J=2.4,2.4,5.4 \mathrm{~Hz}, 1 \mathrm{H}), 5.79(\mathrm{~s}, 1 \mathrm{H})$, 5.98-6.01 (m, 1H); ${ }^{13} \mathrm{C}$ NMR $\left(150 \mathrm{MHz}, \mathrm{CDCl}_{3}\right) \delta 38.4,38.5,41.2$ 57.0, 61.8, 130.4, 140.1, 162.5, 163.8; IR (thin film) 1576, $2921 \mathrm{~cm}^{-1}$; HRMS (ESI) $m / z[\mathrm{M}+\mathrm{Na}]^{+}$: calcd for $\mathrm{C}_{11} \mathrm{H}_{16} \mathrm{ClN}_{4} \mathrm{O}^{+}, 255.1013$; found, 255.1013 .

4.1.10. (+)-2-((1S,4R)-4-(2,5-Diamino-6-chloropyrimidin-4-ylamino) cyclopent-2-enyl)ethanol (19). A solution of $p$-chloroaniline $(125 \mathrm{mg}$, $0.981 \mathrm{mmol})$ in $3 \mathrm{~N} \mathrm{HCl}(2 \mathrm{~mL})$ was stirred at $0{ }^{\circ} \mathrm{C}$. To this solution was added a solution of sodium nitrite $(68 \mathrm{mg}, 0.981 \mathrm{mmol}$ ) in water $(0.8 \mathrm{~mL})$ and the mixture was allowed to stir at $0{ }^{\circ} \mathrm{C}$ for $10 \mathrm{~min}$. The resultant diazonium salt solution was added to a mixture of cyclopentene $(+)-18(200 \mathrm{mg}, 0.785 \mathrm{mmol})$, acetic acid $(4 \mathrm{~mL})$, water 
( $4 \mathrm{~mL}$ ), and sodium acetate trihydrate $(1.6 \mathrm{~g})$. The reaction mixture was stirred overnight at $\mathrm{rt}$. The yellow precipitate was filtered and washed with cold water until the eluting filtrate was $\mathrm{pH}$ 7. The solids were dried under vacuum to yield $220 \mathrm{mg}$ of the aryl azo compound (71\%). A portion $(210 \mathrm{mg})$ of the material was dissolved in water $/ i$ PrOH (6 mL/6 mL) and $\mathrm{Zn}$ dust (349 mg, $5.33 \mathrm{mmol}$ ) was added. The mixture was stirred at $90{ }^{\circ} \mathrm{C}$ for $1.5 \mathrm{~h}$. The reaction mixture was concentrated to solids. The crude material was adsorbed on silica gel and purified by column chromatography (silica gel; eluted with $3 \%$ $\mathrm{CH}_{3} \mathrm{OH} / \mathrm{CH}_{2} \mathrm{Cl}_{2}$ to remove $p$-chloroaniline and other impurities, then $5 \% \mathrm{CH}_{3} \mathrm{OH} / \mathrm{CH}_{2} \mathrm{Cl}_{2}$ to elute product) to afford $115 \mathrm{mg}$ of ( + )-19 as an oil (80\%). $[\alpha]_{\mathrm{D}}^{20}+104\left(c 0.1, \mathrm{CH}_{3} \mathrm{OH}\right) ;{ }^{1} \mathrm{H}$ NMR (600 $\left.\mathrm{MHz}, \mathrm{CD}_{3} \mathrm{OD}\right)$ o $1.51-1.58(\mathrm{~m}, 1 \mathrm{H}), 1.65-1.72(\mathrm{~m}, 1 \mathrm{H}), 1.91-2.01(\mathrm{~m}, 2 \mathrm{H}), 2.95-3.02$ $(\mathrm{m}, 1 \mathrm{H}), 3.59-3.66(\mathrm{~m}, 2 \mathrm{H}), 5.14-5.18(\mathrm{~m}, 1 \mathrm{H}), 5.81$ (ddd, $J=1.8,2.1$, $6.0 \mathrm{~Hz}, 1 \mathrm{H}$ ), 5.98 (ddd, $J=1.8,2.1,6.0 \mathrm{~Hz}, 1 \mathrm{H}) ;{ }^{13} \mathrm{C}$ NMR $(150 \mathrm{MHz}$, $\left.\mathrm{CD}_{3} \mathrm{OD}\right) \delta 39.3,39.8,42.4,58.0,61.8,114.7,132.1,139.9,142.9,157.3$, 158.2; IR (thin film) 1443, 1565, 2864, 2926, $3359 \mathrm{~cm}^{-1}$; HRMS (ESI) $\mathrm{m} / z[\mathrm{M}+\mathrm{H}]^{+}$: calcd for $\mathrm{C}_{11} \mathrm{H}_{17} \mathrm{ClN}_{5} \mathrm{O}^{+}, 270.1122$; found, 270.1118 .

4.1.11. (+)-2-((1S,4R)-4-(2-Amino-6-chloro-9H-purin-9-yl)cyclopent-2-enyl)ethanol (20). A mixture of (+)-19 (115 mg, $0.426 \mathrm{mmol})$, triethyl orthoformate $(2.5 \mathrm{~mL})$, and hydrochloric acid $(12 \mathrm{M}, 0.11 \mathrm{~mL})$ was stirred overnight at rt. The mixture was concentrated to a tan solid. A dilute solution of hydrochloric acid $(0.5 \mathrm{M}, 4 \mathrm{~mL})$ was added and the mixture was stirred at rt for $1 \mathrm{~h}$. The mixture was neutralized to $\mathrm{pH} 8$ with $1 \mathrm{M}$ sodium hydroxide and concentrated to tan solids. The crude material was adsorbed on silica gel and purified by column chromatography (silica gel; eluted with $8 \% \mathrm{CH}_{3} \mathrm{OH} / \mathrm{CH}_{2} \mathrm{Cl}_{2}$ ) to afford $85 \mathrm{mg}$ of $(+)-20$ as an off-white oil (72\%). $[\alpha]_{\mathrm{D}}^{2 \mathrm{O}}+68$ (c 0.1, $\left.\mathrm{CH}_{3} \mathrm{OH}\right) ;{ }^{1} \mathrm{H}$ NMR $\left(600 \mathrm{MHz}, \mathrm{CD}_{3} \mathrm{OD}\right)$ $\delta$ 1.57-1.64 (m, 1H), 1.78 (dddd, $J=6.6,7.2,7.2,13.2 \mathrm{~Hz}, 1 \mathrm{H}), 2.14$ (ddd, $J=6.6,8.1,14.1 \mathrm{~Hz}, 1 \mathrm{H}$ ), 2.19 (ddd, $J=3.0,7.5,14.1 \mathrm{~Hz}, 1 \mathrm{H}$ ), $3.16-3.23(\mathrm{~m}, 1 \mathrm{H}), 3.61-3.70(\mathrm{~m}, 2 \mathrm{H}), 5.59-5.63(\mathrm{~m}, 1 \mathrm{H}), 5.91$ (ddd, $J=2.4,2.4,5.4 \mathrm{~Hz}, 1 \mathrm{H}), 6.29$ (ddd, $J=1.8,1.8,6.0 \mathrm{~Hz}, 1 \mathrm{H}), 7.94(\mathrm{~s}, 1 \mathrm{H})$; ${ }^{13} \mathrm{CNMR}\left(150 \mathrm{MHz}, \mathrm{CD}_{3} \mathrm{OD}\right) \delta 39.2,39.2,43.0,61.4,61.6,125.4,128.7$, 142.7, 144.0, 151.5, 155.0, 161.6; IR (thin film) 1447, 2859, 2929, $3305 \mathrm{~cm}^{-1}$; HRMS (ESI) $\mathrm{m} / z[\mathrm{M}+\mathrm{Na}]^{+}$: calcd for $\mathrm{C}_{12} \mathrm{H}_{14} \mathrm{ClN}_{5} \mathrm{ONa}^{+}$, 302.0779; found, 302.0785 .

\section{Acknowledgements}

We would like to thank Dr. Jed Fisher (University of Notre Dame) for helpful discussions, Dr. Bill Boggess (University of Notre Dame) and Nonka Sevova (University of Notre Dame) for mass spectroscopic analyses, and Dr. Jaroslav Zajicek (University of Notre Dame) for NMR assistance. We acknowledge the NIH (GM068012) for support of this work. L.P.T. acknowledges a Wolf Fellowship (2009, UND).

\section{Supplementary data}

Supplementary data associated with this article can be found in the online version at doi:10.1016/j.tet.2010.11.097.

\section{References and notes}

1. (a) Agrofoglo, L.; Suhas, E.; Farese, A.; Condom, R.; Challand, S. R.; Earl, R. A.; Guedj, R. Tetrahedron 1994, 50, 10611; (b) Crimmins, M. T. Tetrahedron 1998, 54, 9229.

2. Vince, R.; Hua, M. J. Med. Chem. 1990, 33, 17.

3. Orr, D. C.; Figueiredo, H. T.; Mo, C.-L.; Penn, C. R.; Cameron, J. M. J. Biol. Chem. 1992, 267, 4177

4. Daluge, S. M.; Good, S. S.; Faletto, M. B.; Miller, W. H.; Clair, S.; M.H.; Boone, L. R.; Tisdale, M.; Parry, N. R.; Reardon, J. E.; Dornsife, R. E.; Averett, D. R.; Krenitsky, T. A. Antimicrob. Agents Chemother. 1997, 41, 1082.

5. Fung, E. N.; Cai, Z.; Burnette, T. C.; Sinhababu, A. K. J. Chromatogr., B 2001, 754, 285.

6. (a) Foster, R. H.; Failds, D. Drugs 1998, 55, 729; (b) Melroy, J.; Nair, V. Curr. Pharm. Des. 2005, 11, 3847; (c) Yuen, G. J.; Weller, S.; Pakes, G. E. Clin. Pharm. 2008, 47, 351.

7. (a) Yang, M.; Schneller, S. W. Bioorg. Med. Chem. Lett. 2005, 15, 149; (b) Roberts, S. M.; Jones, M. F. J. Chem. Soc., Perkin Trans. 1 1988, 2927.

8. Olivo, H. E.; Yu, J. Tetrahedron: Asymmetry 1997, 8, 3785.

9. (a) Rhee, H.; Yoon, D.; Jung, M. E. Nucleosides, Nucleotides Nucleic Acids 2000, 19, 619; (b) Akella, A. B.; Vince, R. Tetrahedron 1996, 52, 2789.

10. (a) Jiang, MX.-W.; Jin, B.; Gage, J. L.; Priour, A.; Savela, G.; Miller, M. J. J. Org. Chem. 2006, 71, 4164; (b) Li, F.; Brogan, J. B.; Gage, J. L.; Zhang, D.; Miller, M. J. J. Org. Chem. 2004, 69, 4538.

11. (a) Cesario, C.; Miller, M. J. J. Org. Chem. 2009, 74, 5730; (b) Cesario, C.; Tardibono, L.; Miller, M. J. Tetrahedron Lett. 2010, 51, 3053.

12. Mulvihill, M. J.; Gage, J. L.; Miller, M. J. J. Org. Chem. 1998, 63, 3357.

13. For $\mathrm{N}-\mathrm{O}$ bond reductions of cycloadducts, see: Cesario, C.; Tardibono, L.; Miller, M. J. J. Org. Chem. 2009, 74, 448 .

14. Tardibono, L.; Patzner, J.; Cesario, C.; Miller, M. J. Org. Lett. 2009, 11, 4076.

15. For examples of guanine base formation, see: (a) Balo, C.; Blanco, J. M.; Fernandez, F.; Lens, E.; Lopez, C. Tetrahedron 1998, 54, 2833.

16. 2-((1R,4R)-4-((2,5-Diamino-6-ethoxypyrimidin-4-yl)amino)cyclopent-2-en-1yl)ethanol was identified (by LC-MS) as a byproduct when the reaction was conducted in $\mathrm{EtOH}$.

17. 2-((1R,4R)-4-(2-Amino-6-ethoxy-9H-purin-9-yl)cyclopent-2-en-1-yl)ethanol was identified (by LC-MS) as a byproduct when prolonged reaction times were allowed.

18. (a) Grumann, A.; Marley, H.; Taylor, R. J. K. Tetrahedron Lett. 1995, 36, 7767.

19. Detailed antiviral assay data for $(-)-\mathbf{3 a},(-)-\mathbf{3 b},(+)-\mathbf{4 a},(+)-\mathbf{4 b}$, and related intermediates can be found in the Supplementary data. 